\title{
Treatment abandonment among patients with HIV infection in a reference center in southeastern Brazil
}

Raquel Tozzo de LIMA ${ }^{1}$

Márcio Cristiano de MELO'

Maria Rita DONALÍSIO'

\begin{abstract}
The aim of this study was to analyze the sociodemographic, epidemiological, clinical and laboratory-related factors associated with the abandonment of antiretroviral therapy (ART) and the clinical and laboratory follow-up data of patients with human immunodeficiency virus (HIV) infection. This retrospective case-control study was conducted in the Reference Centre for Sexually Transmitted Diseases AIDS of Campinas-SP, from 2010 to 2015, with 50 cases of treatment abandonment and 66 cases with treatment and regular follow-ups. After univariate analysis, the multiple logistic regression model was adjusted using the cases, controls and covariables of interest. Being black/brownskinned, unemployed and heterosexual, and having a smoking habit were associated with abandonment, while a higher level of education and the presence of a multi-professional healthcare team predicted adherence to ART and follow-up. Hence, ART abandonment and follow-up are associated with unfavorable socioeconomic indicators and not with the integral care to patients. Our results may help in the identification of patients at a risk of abandoning treatment and follow-up, and formulation of prevention strategies for the same.
\end{abstract}

Keywords: HIV, AIDS, adherence, antiretroviral therapy, sero-diagnosis of AIDS, serology of AIDS, Brazil.

\section{INTRODUCTION}

Since the late 1990s, antiretroviral drugs have been considered highly effective in controlling human immunodeficiency virus (HIV) replication, and their use has modified the natural history of HIV as well as significantly reduced the associated morbidity and mortality [1, 2].

In several parts of the world, adherence to antiretroviral therapy (ART) and the loss of followup among people living with HIV/acquired immune deficiency syndrome (AIDS) (PLHA) affect prognoses $[3,4]$.

The use of antiretroviral drugs significantly controls the HIV viral load in the blood [1] and semen (4), thereby reducing the rates of viral transmission and thus, the occurrence of new infections [5,6]. However, United Nations Programme on HIV/AIDS (UNAIDS) data for 2016 show that, worldwide, there has been no significant reduction in the prevalence of HIV infection. In fact, in Latin America, the prevalence rate increased at $2 \%$ per year, from 2010 to 2015 [7]. Thus, the goals proposed by the UNAIDS in the document '90/90/90'
(8), which calls for $90 \%$ diagnosis, treatment and viral suppression by 2020, remain a challenge in Brazil and worldwide.

Limited access to care in several parts of the world, as well as individual problems associated with adherence to ART and follow-up may explain the current HIV pandemic situation [9].

Studying these factors in each country and, in each PLHA-specialized service, may contribute to the formulation of direct specific strategies in each service and the global effort to eradicate the HIV pandemic.

Thus, the present study analyzed the sociodemographic, epidemiological, clinical and laboratory-related factors associated with ART abandonment and follow-up among users of the Reference Center for Sexually Transmitted Diseases/ AIDS (CRIST/AIDS) in Campinas, São Paulo (SP).

\section{METHODS}

This retrospective case-control study aimed to identify the risk factors associated with treatment abandonment and clinical laboratory follow-up among

\footnotetext{
1 Universidade Estadual de Campinas, Faculdade de Ciências Médicas, Programa de Pós-graduação em Saúde Coletiva. Rua Tessália Vieira de Camargo, 126, 13083-997, Campinas, SP, Brasil. Correspondência para / Correspondence to: RT LIMA. E-mail: <tumoca@uol.com.br>. 
HIV-positive patients followed-up from 2010 to 2015 in the CRIST/AIDS of Campinas-SP. This specialized attention service is involved in providing assistance, as well as in the prevention and treatment of sexually transmitted infections (STIs)/AIDS. It is also responsible for training and the development of matrix-based strategies in the Campinas basic network, for the care and prevention of STIs.

The medical records of adult patients who had abandoned ART for 365 days or more were selected from the list provided by the Logistic Control System of Medicines (LCSOM) in July 2015 (cases). The control group comprised patients with ART use for at least 365 days, and the period analyzed was from March 2014 to March 2015. This period was considered because, since April 2015, a new ART formulation was introduced, which involves a smaller number of pills (combination formulation of tenofovir, lamivudine and efavirenz - "3 in 1"), which could offer a dosage advantage to the control group. In both groups, those with an entry date prior to 2010 were excluded, to analyze individuals with contemporaneous HIV infection. We also excluded from both groups those who used the service only as a dispensary of antiretroviral medicine, patients transferred to other services, those who died and those whose records were not found.

In the control group, patients with ART use for less than 365 days and those without ART use for 30 days or more on 3 or more occasions were excluded, in addition to one patient taking 'tenofovir and lamivudine coformulation - "2 in 1 ", the distribution of which began in February 2015 in the CRIST/AIDS.

The variables collected pertained to demographics (sex, age and ethnicity/color); socioeconomic conditions (education, occupation, origin and housing); epidemiology and behavior (date of diagnosis, sexual orientation, exposure category, condom use, sexual partnership, history of sexually transmitted diseases (STDs), drug addiction, smoking and alcoholism); clinics (occurrence of opportunistic diseases, classes of ART used, intolerance to ART, presence of mental illnesses, use of psychotropic medications and presence of comorbidities); counts of CD4 T lymphocytes and HIV viral load at entry to the service and the last recorded values in the medical records, and the time elapsed between the diagnosis of HIV and development of AIDS); type of health service (multi-professional team service) and service adherence strategies (host activities, therapeutic groups, assisted treatment and, telephone search). Specific variables related to the control group were the regular use of antiretrovirals and attending medical appointments.

The frequencies of the variables obtained in the case and control files were calculated. To compare the observed proportions, a Chi-square test and Fisher's exact test were used for variables with categories that presented $\mathrm{n} \leq 5$. The means of the continuous variables were compared by a Student's t-test. In all the statistical tests, the level of significance was set at $5 \%(p \leq 0.05)$. After univariate analysis, a multiple logistic regression model was adjusted considering the cases $(y=1)$ and controls $(y=0)$, and the covariables of interest. These entered the model if $p<0.25$ in the univariate analysis and remained in the final model (via stepwise) if $p \leq$ 0.05. Epi Info 7 for Windows software was used to compile and organize data and IBM SPSS Statistics 21 for Windows to perform the statistical analysis.

This research was approved by the Research Ethics Committee of FCM/Unicamp, SP (process number 1.332.499).

\section{RESULTS}

A list provided by LCSOM in July 2015 allowed for the identification of 211 CRIST/AIDS users who did not receive ART at the pharmacy for 365 days or more (cases). After the exclusion criteria were applied, the medical records of 50 patients were examined. The pharmacy service provided a list of names of 801 patients who actively withdrew from ART, of whom 97 patients were randomly selected. After the application of the exclusion criteria, 66 patients (controls) remained.

Table 1 shows the demographic variables of the cases and controls. There was a difference between the groups in relation to the following variables: race/color, age group, work condition, housing condition and level of specialization required by the occupation (Table 1). The mean age of the case group was 33.7 years and that of the control group was 39.1 years, with a significant difference observed in the ' 50 years or more' age group (Table 1). The case group comprised a higher number of institutionalized individuals, homeless people and unemployed people than the control group. Those in the case group frequently had an education level of only up to 4 years, and 5 cases (10\%) were uneducated (none of the control patients were uneducated); however, these differences were not statistically significant 
(Table 1). Three individuals in the case group and one in a larger number of patients involved in labor activities that the control group were homeless. The control group had require greater education levels $(p=<0.01)$.

Table 1. Sociodemographic characteristics of the case and control groups, Campinas (SP).

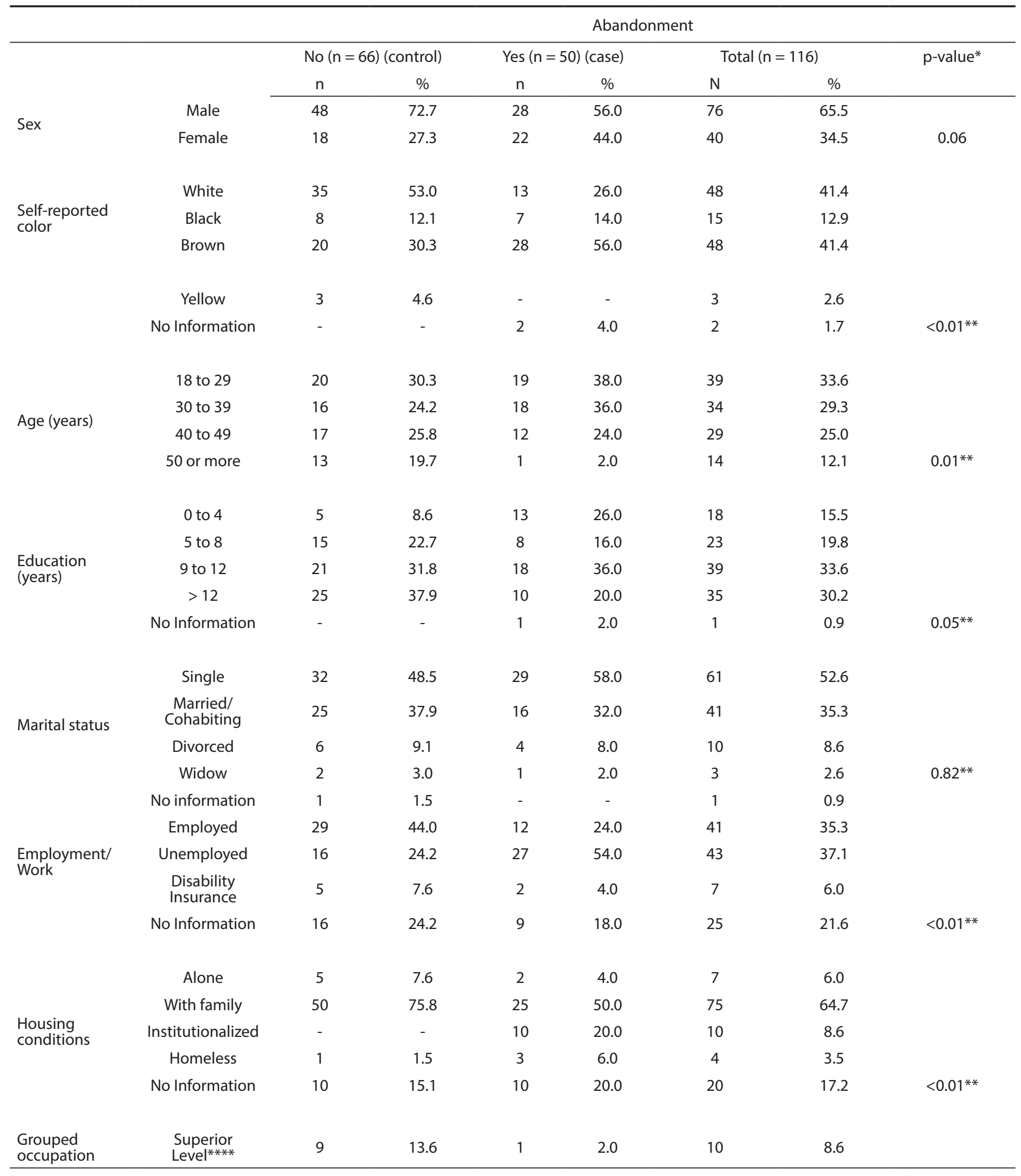




\begin{tabular}{|c|c|c|c|c|c|c|c|c|}
\hline & Technical Level & 14 & 21.2 & 4 & 8.0 & 18 & 15.5 & \\
\hline & Services & 23 & 34.9 & 28 & 56.0 & 51 & 44.0 & $<0.01$ \\
\hline & $\begin{array}{l}\text { Others } \\
\text { no inf*** or } \\
\text { notion }\end{array}$ & 20 & 30.3 & 17 & 34.0 & 37 & 31.9 & \\
\hline \multirow{3}{*}{ City of origin } & Campinas & 61 & 92.4 & 42 & 84.0 & 103 & 88.8 & \\
\hline & $\mathrm{RMC}^{* *}$ & 5 & 7.6 & 4 & 8.0 & 9 & 7.8 & \\
\hline & Others SP*** & 0 & - & 4 & 8.0 & 4 & 3.4 & 0.06 \\
\hline
\end{tabular}

Regarding sexual orientation, a higher number of those in the control group were men who have sex with men (MSM) and MSM was the predominant category of sexual exposure in both groups (Table 2). The active use of drugs was more frequently observed in the case group than the control group, at $40 \%$ and $16.7 \%$, respectively $(p=0.01)$. The proportion of tobacco use was statistically higher in the case group $(p=<0.01)$.

Table 2. Epidemiological characteristics and backgrounds of the case and control groups, Campinas (SP).

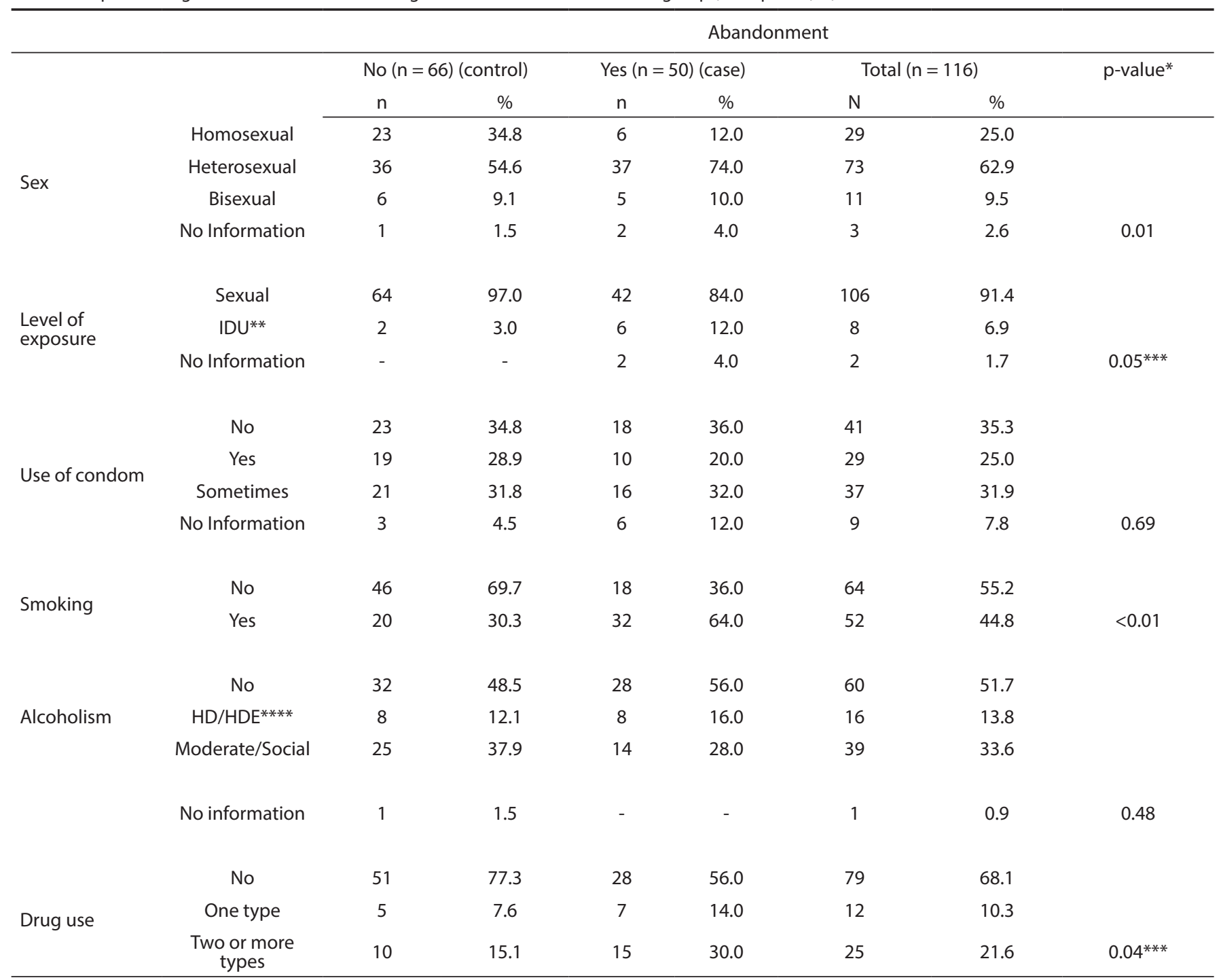

Note: *In the Chi-square test, significance was set at 0.05 . For the Chi-square test, the "no information" category was removed. ${ }^{* *}$ IDU, injectable drug user. ${ }^{* * *}$ Fisher's exact test for categories with $n \leq 5$. ${ }^{* * *} \mathrm{HD}$, heavy drinker; HED, heavy episodic drinker. 
Table 3 shows the results of the univariate analysis of the clinical characteristics of the groups studied and the characteristics of the care service. Comorbidities were more frequently observed among patients undergoing treatment and follow-up (around 48\%). None of the clinical characteristics analyzed varied between the groups. It is worth noting, however, that ART intolerance was quite frequently observed both in the group that abandoned ART and among those taking antiretroviral drugs (Table 3).

As for the type of health service, the only variable that was statistically significantly different between the groups was the presence of multi-professional care, which was less accessible to those in the case group ( $p=0.01$ ) (Table 3). In both groups, a high proportion of people sought care from social workers, at $48 \%$ (case group) and $53 \%$ (control group). In the case group, dentists were the most sought-after professionals (30\% of the cases and $21.2 \%$ of the controls) and in the control group, nutritionists were the most sought-after ( $8 \%$ of the cases and $30.3 \%$ of the controls).

Table 3. Clinical characteristics of the studied populations and the care service, Campinas (SP).

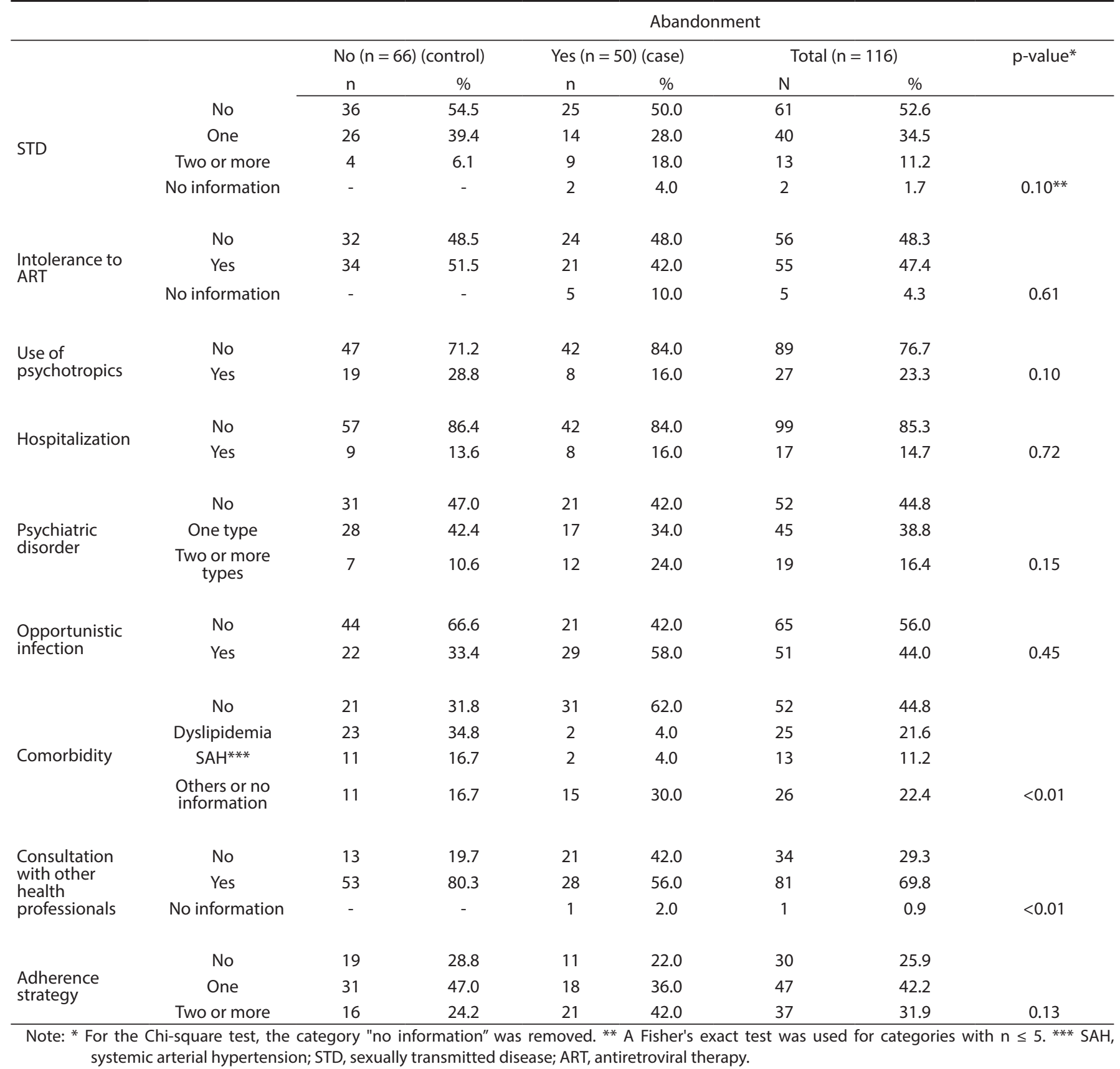


The last CD4 outcome differed significantly between the cases and controls, as did the proportions of those in whom an undetectable viral load $(<50$ copies $/ \mathrm{mL}$ ) was achieved at the end of the study analysis period. Among the controls, the last CD4 count recorded was 1.5 times higher than that among patients who had abandoned treatment and followup. A higher number of patients in the control group had a final undetectable HIV viral load in their medical records (Table 4)

Table 4. Clinical characteristics of the studied populations and the care service, Campinas (SP).

\begin{tabular}{|c|c|c|c|c|c|c|c|}
\hline & & \multicolumn{6}{|c|}{ Abandonment } \\
\hline & & \multicolumn{2}{|c|}{ No $(n=66)$ (control) } & \multicolumn{2}{|c|}{ Yes $(n=50)$ (case) } & \multirow[b]{2}{*}{$* t$} & \multirow[b]{2}{*}{$p$-value } \\
\hline & & $\mathrm{n}$ & $\%$ & $\mathrm{n}$ & $\%$ & & \\
\hline \multirow{2}{*}{$\begin{array}{l}\text { Mean CD4 (cells/ } \\
\text { mm3) }\end{array}$} & Entrance & 376.1 & & 384.1 & & -0.17 & $0.87^{*}$ \\
\hline & Last & 609.3 & & 394.5 & & 4.42 & $<0.01^{*}$ \\
\hline \multirow{2}{*}{$\begin{array}{l}\text { Mean viral load } \\
\text { (copies/mL) }\end{array}$} & Entrance & 161529.2 & & 53480.2 & & 1.84 & $0.07^{*}$ \\
\hline & Last & 22948.7 & & 29771.6 & & -0.23 & $0.82^{*}$ \\
\hline \multirow{2}{*}{$\begin{array}{l}\text { Initial CD4 (cells/ } \\
\text { mm3) }\end{array}$} & Maximum & 1161 & & 976 & & & \\
\hline & Minimum & 8 & & 16 & & & \\
\hline \multirow{2}{*}{$\begin{array}{l}\text { Final CD4 (cells/ } \\
\text { mm3) }\end{array}$} & Maximum & 735 & & 980 & & & \\
\hline & Minimum & 7 & & 22 & & & \\
\hline \multirow{2}{*}{$\begin{array}{l}\text { Viral load <50 } \\
\text { copies } / \mathrm{mL}\end{array}$} & Entrance & 10 & 15.1 & 5 & 10 & & $0.30^{* *}$ \\
\hline & Last & 51 & 77.3 & 11 & 16.7 & & $<0.01^{* *}$ \\
\hline
\end{tabular}

Note: * Student's t-test for comparisons between the CD4 means and human immunodeficiency virus viral load. ** Fisher's exact test for categories with $\mathrm{n} \leq 5$.

Regarding the use of antiretroviral drugs of different classes, a higher number of those in the control group used 2 nucleoside reverse transcriptase inhibitors/nucleotide (NRTIs) and 1 nonnucleoside reverse transcriptase inhibitor (NNRTIs) (64\% controls and $44 \%$ cases, $p=0.05$ ) and, among the cases, a higher number of patients used 2 NRTIs and 1 protease inhibitor $(\mathrm{PI})(42 \%$ cases and $22.7 \%$ controls, $\mathrm{p}=0.04)$.

The mean number of months taken for AIDS development was 30.6 months among the cases and 21.92 months among the controls $(p=0.43)$. In $16 \%$ of the cases and $22.7 \%$ of the controls, the diagnoses of HIV and AIDS were concomitant. The maximum time interval for the evolution of AIDS was 270 months in the cases and 266 months in the controls.

Among the controls, the analysis of the regularity of follow-up and use of ART showed that 59.1\% regularly attended consultations with infectologists and $75.7 \%$ received ART regularly in the pharmacy.

In the multivariate analysis, we identified the following variables as being risk factors for abandonment: black/brown self-reported color, being unemployed, being heterosexual and being a smoker. Higher education levels and attendance by a multiprofessional team appeared to provide protection against abandonment (Table 5).

Table 5. Proportional odds ratio of the variables associated with the abandonment of follow-up and antiretroviral therapy, and the univariate and multiple models in people living with HIV/AIDS in Campinas (SP).

\begin{tabular}{|c|c|c|c|c|c|c|c|}
\hline & & \multicolumn{2}{|c|}{ Univariate } & \multicolumn{4}{|c|}{ Multiple } \\
\hline \multirow{3}{*}{ Sex } & & OR & $95 \% \mathrm{Cl}$ & $\mathrm{p}$-value & OR & $95 \% \mathrm{Cl}$ & $p$-value \\
\hline & Male & 1 & - & & - & - & - \\
\hline & Female & 2.09 & $1.00-4.56$ & 0.06 & & & \\
\hline Age & - & 0.95 & $0.92-0.99$ & 0.01 & - & - & - \\
\hline \multirow{2}{*}{ Self- reported color } & White & 1 & - & & 1 & - & \\
\hline & Black/Brown & 3.62 & $1.68-8.18$ & 0.00 & 6.99 & $1.57-30.97$ & 0.01 \\
\hline
\end{tabular}




\begin{tabular}{|c|c|c|c|c|c|c|c|}
\hline \multirow{3}{*}{ Education in years } & 0 to 4 & 1 & - & & 1 & - & \\
\hline & 5 to 8 & 0.20 & $0.05-0.78$ & & 0.04 & $0.00-0.41$ & 0.01 \\
\hline & $\geq 9$ & 0.23 & $0.07-0.72$ & 0.01 & 1.96 & $0.27-14.18$ & 0.50 \\
\hline \multirow{2}{*}{ Work, employment } & $\begin{array}{l}\text { Employed/ Disability } \\
\text { Insurance }\end{array}$ & 1 & - & & 1 & - & \\
\hline & Unemployed & 4.09 & $1.70-9.85$ & 0.00 & 7.03 & $1.79-27.63$ & 0.00 \\
\hline \multirow{2}{*}{ Sexual orientation } & $\begin{array}{c}\text { Homosexual/ } \\
\text { Bisexual }\end{array}$ & 1 & - & & 1 & - & \\
\hline & Heterosexual & 2.88 & $1.25-6.62$ & 0.01 & 7.83 & $1.33-45.85$ & 0.02 \\
\hline \multirow{2}{*}{ Exposure category } & Sexual & 1 & - & - & 1 & - & - \\
\hline & IDU & 4.57 & $0.88-23.73$ & 0.1 & & & \\
\hline \multirow{2}{*}{ Smoking* } & No & 1 & - & - & 1 & - & - \\
\hline & Yes & 4.08 & $1.87-8.92$ & 0.00 & 10.90 & $2.72-43.59$ & 0.00 \\
\hline \multirow{2}{*}{ STD } & No & 1 & - & - & - & - & - \\
\hline & Yes & 0.90 & $0.43-1.90$ & 0.79 & & & \\
\hline \multirow{2}{*}{$\begin{array}{l}\text { Psychiatric } \\
\text { disorder }\end{array}$} & No & 1 & - & - & - & - & - \\
\hline & Yes & 1.22 & $0.58-2.56$ & 0.59 & & & \\
\hline \multirow{2}{*}{$\begin{array}{l}\text { Consultation } \\
\text { with other } \\
\text { professionals** }\end{array}$} & No & 1 & - & - & 1 & - & -- \\
\hline & Yes & 0.32 & $0.14-0.75$ & 0.00 & 0.18 & $0.04-0.91$ & 0.04 \\
\hline \multirow{3}{*}{ Drug use } & No & 1 & - & - & - & - & - \\
\hline & One type & 2.55 & $0.74-8.78$ & & & & \\
\hline & Two or more & 2.73 & $1.08-6.87$ & 0.03 & & & \\
\hline \multirow{2}{*}{ ART intolerance } & No & 1 & - & - & - & - & - \\
\hline & Yes & 0.82 & $0.38-1.75$ & 0.61 & & & \\
\hline \multirow{3}{*}{$\begin{array}{l}\text { Adherence } \\
\text { strategies *** }\end{array}$} & No & 1 & - & & - & - & - \\
\hline & Once & 1.00 & $0.39-2.57$ & & & & \\
\hline & Twice or more & 2.26 & $0.84-6.08$ & 0.10 & & & \\
\hline
\end{tabular}

Note: *Smoking - if active smoker. ${ }^{* *}$ Consultation with professionals besides the doctor and nurse. ** Reception, therapeutic groups, assisted treatment and telephone search. ART, antiretroviral therapy; STD, sexually transmitted disease; IDU, injectable drug user; OR, odds ratio; Cl, confidence interval

\section{DISCUSSION}

The results of the study show that the group of patients who abandoned treatment and follow-up in the CRIST/AIDS largely comprised people who were young adults, male, brown, single, unemployed or in occupations that did not require university or technical specialization, and lived with relatives or had no housing. A total of $15.5 \%$ of them were illiterate or had only up to 4 years of education. These patients were predominantly Catholics or evangelicals and lived in the city of Campinas-SP. A majority of them presented the following epidemiological characteristics: heterosexuality, smoking habit, moderate use of alcoholic beverages and abuse of one or more types of drugs. Before abandoning their treatment and follow-up, these people used 2 NRTIs and 1 NNRTIs or 2 NRTIs and $1 \mathrm{PI}$, and had some type of intolerance to ART. They had a mean CD4 count of 384.1 cells $/ \mathrm{mm} 3$ and an average HIV viral load of $53,480.2$ copies $/ \mathrm{mL}$. The average number of months to AIDS progression was 30.56 .

After the multivariate analysis of the data, the predictors of treatment abandonment and follow-up 
were: race/color black or brown, unemployed status, heterosexual orientation and smoking, while being attended to by a multi-professional team and having over 5 years of education were negatively associated with the abandonment of treatment and follow-up.

The population that abandoned treatment and follow-up in the CRIST/AIDS had unfavorable socioeconomic conditions, as also observed in other studies $[3,10,11]$. Apart from having a lower education level, these people were less professionally prepared and frequently had occupations not requiring technical or university specialization. In a study carried out in Oromia (Ethiopia), $51.4 \%$ of the patients who abandoned treatment and follow-up were informal workers, while $36.3 \%$ of the controls were wage earners, reflecting that those undergoing treatment and follow-up were likely in the specialized workforce [12].

The case group had a higher number of individuals who were brown; this could be attributed, in part, to the changes in the racial composition in Brazil, as observed in the 2010 Brazilian Demographic Census [13]. According to this document, the proportion of brown-skinned people increased from $38.5 \%$ in 2000 to $43.1 \%$, while the proportion of white-skinned people decreased from $53.7 \%$ to $47.7 \%$ and that of black-skinned people rose from $6.2 \%$ to $7.6 \%$. According to the 2010 census, the living conditions of the brown and black population were worse than those of the white and yellow populations, since brown-skinned people, together with black-skinned people, had an income that was 2 to 3 times lower than that of white- and yellow-skinned people [14]. This may explain the higher percentage of brown and blackskinned people in the case group, as socioeconomic factors associated with precarious living conditions could favor treatment and follow-up abandonment.

Only those in the case group tended to live in institutions such as prisons, shelter homes or detox clinics, or be homeless. A study conducted in India showed that being homeless, male, illiterate and over 45 years of age are risk factors for the loss of HIV-related follow-up and/ or death [15].

In the present study, a higher proportion of heterosexual patients was observed in the case group. Zhou et al. [16] found that a high proportion of patients (64\%) with heterosexual exposure abandoned treatment and follow-up. A North American review of literature showed an association between male heterosexuality in situations of socioeconomic precariousness and an increased risk of HIV infection, as well as a lower access to diagnosis, treatment and disease care [17]. Although there may be information biases surrounding this variable, factors associated with sex, such as the feeling of masculinity, could also keep men away from taking care of their health [18]. As for women, existing literature shows that those with an overload of functions as providers and caregivers of their families have worse adherence rates and more frequently abandon treatment and follow-up. A study in a specialized HIV treatment center in New Orleans, USA, showed an improvement in treatment adherence among women when the health service began providing care to their children during the medical visit [19].

Precarious socioeconomic conditions, being single, using drugs and having depression are related to poor adherence among women in the United States [20]. Our observation, pertaining to the high number of MSM in the control group, may reflect that the understanding of a higher risk of infection can promote prevention attitudes $[21,22]$. This fact corroborates the fact that the individuals in this group present more years of schooling in relation to those in the case group, which theoretically, is associated with better comprehension capacity and better socioeconomic conditions. Remien's study [21] on the association between poor adherence to ART and unsafe sex according to sex and sexual orientation, found that the only significant demographic differences between the MSM and heterosexual populations studied pertained to education and white skin color.

Tobacco use was significantly higher in the case group ( $p=<0.01$ ). This finding is in line with the 2011 AIDS Clinical Trial Group in which smoking, in addition to intravenous drug use, male sex and having under 16 years of education, appeared as factors associated with the loss of treatment and follow-up among patients who had not yet started ART [23]. Additionally, Carvalho et al. [24] showed a higher percentage of smokers among patients without treatment adherence. However, some studies found no association between smoking and adherence $[10,25]$. One possible explanation is that a higher number of smokers may abandon treatment as nicotine dependence may be associated with psychiatric disorders, such as anxiety and depression [26] and such disorders are related to poor adherence to antiretrovirals [27]. The present study found no association between depression or anxiety and poor adherence to ART and/or follow-up, although this association has been frequently observed 
$[25,28]$. A greater number of abandonment cases were observed among those with chemical dependency, which is consistent with the presence of a greater number of drug users in the case group. Both intuitively and based on the literature, there is a consensus that the non-use of any type of drug is a factor that ensures better adherence to general medical treatments, as well as to ART [17, 29]. A systematic review of 42 studies on the subject concluded that active drug use is associated with poorer adherence, depression, and lower social support [29].

The findings also show that a higher number of patients in the control group received multi-professional care (involving professionals besides doctors and nurses), and social workers were the most sought-after professionals, both in the case and control groups. The second most sought-after professionals in the case and control groups were dentists and nutritionists, respectively [24]. In the present study, prior to the abandonment of treatment and follow-up, patients sought a higher level of care from dentists, reflecting a worse socioeconomic status compared to those in the control group; this feature has also been suggested in a literature review study that associated poor oral health conditions with poor socioeconomic conditions [30].

The highest number of patients in the control group was attended to by a nutritionist, possibly because the patients who left treatment and follow-up were lessfrequently attended by the nutritionist as they were not referred by health professionals, or because the patients themselves did not want to go through the nutritionist. The second possibility of the patient not wanting to see the nutritionist opens a range of possible reasons, but all of them pertain to inadequate communication between professionals and patients. In any case, the reception of multi-professional care may reflect patients' greater level of self-care; this may also be reflected in their adherence to antiretrovirals.

In this study, we used a period of 365 days or more for the definition of the abandonment of treatment and follow-up, and this allowed for a more accurate identification of the cases of abandonment due to greater specificity [31]. Other authors who investigated the factors associated with the loss of treatment and follow-up also used a period of a year or more to define abandonment [32-34].

Among the limitations of the present study are the small sample size, and the use of secondary data, with inadequate filling, generating a high percentage of ignored data. The reasons for abandonment and the patients' perception of their living conditions and care were not studied, which would have allowed for a better understanding of the contexts of abandonment.

\section{CONCLUSION}

The abandonment of ART and follow-up were associated with factors that represent unfavorable socioeconomic conditions such as being black- or brown-skinned and being unemployed. Higher levels of education and the presence of care by a multi-professional team appeared to protect against abandonment. Ensuring access to other professionals is integral to the care of PLHA, and may contribute to patients' adherence to the service.

Being heterosexual and having a smoking habit also appeared to be associated with abandonment and may be indirectly related to precarious socioeconomic conditions, substance abuse and reactive depression to HIV diagnosis.

The results of this study reinforce the need for investments in the reception and counseling of patients, in the agile identification of those prone to abandonment, and in the formulation of strategies aimed at social and economic support for individuals facing difficulties in attending the service. In addition, a greater health team involvement in the identification of strategies could have an impact on patients' adherence to the service and lead to a consequent reduction in the rates of treatment abandonment and clinical follow-up.

\section{REFERENCES}

1. Hammer SM, Squires KE, Hughes MD, Grimes JM, Demeter LM, Currier JS, et al. A controlled trial of two nucleoside analogues plus indinavir in persons with human immunodeficiency virus infection and CD4 cell counts of 200 per cubic millimeter or less. AIDS Clinical Trials Group 320 Study Team. N Engl J Med. 1997;337(11):725-33. doi: 10.1056/NEJM199709113371101

2. Palella FJ, Delaney KM, Moorman AC, Loveless MO, Fuhrer J, Satten GA, et al. Declining morbidity and mortality among patients with advanced human immunodeficiency virus infection. HIV Outpatient Study Investigators. N Engl J Med. 1998;338(13):853-60. doi: 10.1056/NEJM199803263381301

3. Giordano TP, Gifford AL, White AC, Suarez-Almazor ME, Rabeneck L, Hartman C, et al. Retention in care: a challenge to survival with HIV infection. Clin Infect Dis. 2007;44(11):1493-9. doi: $10.1086 / 516778$ 
4. Vernazza PL, Troiani L, Flepp MJ, Cone RW, Schock J, Roth F, et al. Potent antiretroviral treatment of HIV-infection results in suppression of the seminal shedding of HIV. The Swiss HIV Cohort Study. AIDS. 2000;14(2):117-21.

5. Gray RH, Wawer MJ, Brookmeyer R, Sewankambo NK, Serwadda D, Wabwire-Mangen F, et al. Probability of HIV-1 transmission per coital act in monogamous, heterosexual, HIV-1-discordant couples in Rakai, Uganda. Lancet. 2001;357(9263):1149-53. doi: 10.1016/S0140-6736(00)04331-2

6. Quinn TC, Wawer MJ, Sewankambo N, Serwadda D, Li $C$, Wabwire-Mangen $F$, et al. Viral load and heterosexual transmission of human immunodeficiency virus type 1. Rakai Project Study Group. N Engl J Med. 2000;342(13):921-9. doi: 10.1056/NEJM200003303421303

7. UNAIDS. Prevention gap report. Geneva: WHO; 2016 [cited 2017 Set 20]. Disponível em: <http://www.unaids.org/sites/ default/files/media_asset/2016-prevention-gap-report_en.pdf >.

8. UNAIDS. 90-90-90 An ambitious treatment target to help end the AIDS epidemic. Geneva: WHO; 2014 [cited 2017 Set 20]. Disponível em: <http://www.unaids.org/sites/default/files/ media_asset/90-90-90_en_0.pdf >.

9. Govindasamy D, Ford N, Kranzer K. Risk factors, barriers and facilitators for linkage to antiretroviral therapy care: a systematic review. AIDS. 2012;26(16):2059-67. doi: 10.1097/ QAD.0b013e3283578b9b

10. Silva JAG, Dourado I, Brito AMd, Silva CALd. Fatores associados à não adesão aos antirretrovirais em adultos com AIDS nos seis primeiros meses da terapia em Salvador, Bahia, Brasil. Cad Saúde Pública. 2015;31:1188-98. doi: 10.1590/0102$311 \times 00106914$

11. Guibu IA, Barros MBA, Donalísio MR, Tayra Â, Alves MCGP. Survival of AIDS patients in the Southeast and South of Brazil: analysis of the 1998-1999 cohort. Cad Saúde Pública. 2011;27:s79-s92. doi: 10.1590/S0102-311X2011001300009

12. Megerso A, Garoma S, Eticha T, Workineh T, Daba S, Tarekegn $M$, et al. Predictors of loss to follow-up in antiretroviral treatment for adult patients in the Oromia region, Ethiopia. HIV AIDS (Auckl). 2016;8:83-92.

13. IBGE - Instituto Brasileiro de Geografia e Estatística. Pesquisa Nacional por Amostra de Domicilios: síntese de indicadores 2009 / IBGE, Coordenação de Trabalho e Rendimento. Rio de Janeiro; 2010.

14. Lamarka G, Vettore M. A nova composição racial brasileira segundo o Censo 2010. Determinantes Sociais da Saúde: portal e observatório sobre iniquidades em saúde; 2012 [citado 2017 Set 20]. Disponível em: <http://dssbr.org/site/2012/01/a-novacomposicao-racial-brasileira-segundo-o-censo-2010>.

15. Alvarez-Uria G, Naik PK, Pakam R, Midde M. Factors associated with attrition, mortality, and loss to follow up after antiretroviral therapy initiation: data from an HIV cohort study in India. Glob Health Action. 2013;6:21682. doi: 10.3402/gha.v6i0.21682

16. Zhou J, Tanuma J, Chaiwarith R, Lee CK, Law MG, Kumarasamy $\mathrm{N}$, et al. Loss to Followup in HIV-Infected Patients from Asia-Pacific Region: Results from TAHOD. AIDS Res Treat. 2012;2012:375217. doi: 10.1155/2012/375217
17. Zaller ND, Fu JJ, Nunn A, Beckwith CG. Linkage to care for HIVinfected heterosexual men in the United States. Clin Infect Dis. 2011;52 Suppl 2:S223-30. doi: 10.1093/cid/ciq046

18. Courtenay WH. Constructions of masculinity and their influence on men's well-being: a theory of gender and health. Soc Sci Med. 2000;50(10):1385-401. doi: 10.1016/S0277-9536(99)00390-1

19. Kissinger P, Cohen D, Brandon W, Rice J, Morse A, Clark R. Compliance with public sector HIV medical care. J Natl Med Assoc. 1995;87(1):19-24.

20. Arnsten JH, Demas PA, Grant RW, Gourevitch MN, Farzadegan $\mathrm{H}$, Howard AA, et al. Impact of active drug use on antiretroviral therapy adherence and viral suppression in HIV-infected drug users. J Gen Intern Med. 2002;17(5):377-81. doi: 10.1046/j.1525-1497.2002.10644.x

21. Remien RH, Dolezal C, Wagner GJ, Goggin K, Wilson IB, Gross $\mathrm{R}$, et al. The association between poor antiretroviral adherence and unsafe sex: differences by gender and sexual orientation and implications for scale-up of treatment as prevention. AIDS Behav. 2014;18(8):1541-7. doi: 10.1007/s10461-013-0656-0

22. Baggaley RF, White RG, Boily MC. HIV transmission risk through anal intercourse: systematic review, meta-analysis and implications for HIV prevention. Int J Epidemiol. 2010;39(4):104863. doi: 10.1093/ije/dyq057

23. Krishnan S, Wu K, Smurzynski M, Bosch RJ, Benson CA, Collier $A C$, et al. Incidence rate of and factors associated with loss to follow-up in a longitudinal cohort of antiretroviral-treated HIV-infected persons: an AIDS Clinical Trials Group (ACTG) Longitudinal Linked Randomized Trials (ALLRT) analysis. HIV Clin Trials. 2011;12(4):190-200. doi: 10.1310/HCT1204-190

24. Carvalho CVd, Merchán-Hamann E, Matsushita R. Determinantes da adesão ao tratamento anti-retroviral em Brasília, DF: um estudo de caso-controle. Rev Soc Bras Med Tropical. 2007;40:555-65.

25. Ventura Â. Adesão à terapêutica anti-retrovírica na infecção VIH/ SIDA: Revisão de Artigos Publicados. Arq Med. 2006;20:37-49.

26. Breslau N. Psychiatric comorbidity of smoking and nicotine dependence. Behav Genet. 1995;25(2):95-101. doi: 10.1007/ BF02196920

27. Paterson DL, Swindells S, Mohr J, Brester M, Vergis EN, Squier $C$, et al. Adherence to protease inhibitor therapy and outcomes in patients with HIV infection. Ann Intern Med. 2000;133(1):2130.

28. Gordillo V, del Amo J, Soriano V, González-Lahoz J. Sociodemographic and psychological variables influencing adherence to antiretroviral therapy. AIDS. 1999;13(13):1763-9.

29. Malta M, Strathdee SA, Magnanini MM, Bastos Fl. Adherence to antiretroviral therapy for human immunodeficiency virus/ acquired immune deficiency syndrome among drug users: a systematic review. Addiction. 2008;103(8):1242-57. doi: 10.1111/j.1360-0443.2008.02269.x

30. Locker D. Deprivation and oral health: a review. Community Dent Oral Epidemiol. 2000;28(3):161-9. doi: 10.1034/j.16000528.2000.280301.x

31. Chi BH, Yiannoutsos CT, Westfall AO, Newman JE, Zhou J, Cesar 
C, et al. Universal definition of loss to follow-up in HIV treatment programs: a statistical analysis of 111 facilities in Africa, Asia, and Latin America. PLoS Med. 2011;8(10):e1001111. doi: 10.1371/journal.pmed.1001111

32. Deribe K, Hailekiros F, Biadgilign S, Amberbir A, Beyene BK. Defaulters from antiretroviral treatment in Jimma University Specialized Hospital, Southwest Ethiopia. Trop Med Int Health. 2008;13(3):328-33. doi: 10.1111/j.1365-3156.2008.02006.x

33. Mocroft A, Kirk O, Aldins P, Chies A, Blaxhult A, Chentsova $\mathrm{N}$, et al. Loss to follow-up in an international, multicentre observational study. HIV Med. 2008;9(5):261-9. doi:

\subsection{1/j.1468-1293.2008.00557.x}

34. Coleman S, Boehmer U, Kanaya F, Grasso C, Tan J, Bradford J. Retention challenges for a community-based HIV primary care clinic and implications for intervention. AIDS Patient Care STDS. 2007;21(9):691-701. doi: 10.1089/apc.2006.0205 